\title{
Social Conditions and Expectations of Customers with Disabilities Regarding Policies and Provision of Accessible Banking Technology
}

\author{
Yanti Setianti ${ }^{1}$, Hanny Hafiar ${ }^{2}$, Priyo Subekti ${ }^{3}$, Centurion Chandratama Priyatna ${ }^{4}$ \\ Faculty of Communication Science, Universitas Padjadjaran, Jl. Raya Bandung-Jatinangor Km 21 \\ Jawa Barat, Indonesia. \\ hanny.hafiar@unpad.ac.id
}

\begin{abstract}
The issue of disability rights as a member of the community is always an animated topic to discuss. There are several advocacy efforts to provide opportunities for the disabled to obtain equal public services, including services from financial institutions. The use of information technology in banking services opens up opportunities for the disabled to enjoy various facilities while eventually still leaves several occurring problems. This study aims to assess the social conditions of visually impaired individuals on their expectations over ATM services. This study uses quantitative descriptive methods with data collection techniques through questionnaires. Visually impaired customers have considered that they have not yet received the fulfillment of their public service rights as members of the community, due to the lack of public knowledge, delayed facility fulfillment, and the lack of implementation of accessibility policy. Visually impaired customers are expecting tutorials on using ATM, volume control featuring auditive notifications when usage errors occurred, and additional auditive facilities for available ATM services.
\end{abstract}

Keywords: Visually Impaired, Technology, Banking, Services, Information.

\section{Introduction}

The development of communication technology has changed the process of public service. Now, the public service process that requires filling out documents does not always require a face-to-face process between the service provider and recipient. The concept of service that involves communication technology certainly gives positive support in the aspects of effectiveness and efficiency, primarily reducing the amount of distance and time usually needed, especially if the service process can be done via cellular phones.

There are several types of public services already using communication technology-based applications. Among them are tax payment services, requests for passports, financial institution services, such as banking services. There is a bank service application that creates an easier way for customers to make transactions via mobile phones. Unfortunately, several studies have addressed the questionable accessibility of mobile phones for the elderly and people with disabilities; one concludes that cell phones did not appear to be designed for users of this group [1]. As a result, it is feared that the rapid development of technological advancements can sharpen the digital divide [2] if the obstacles faced by this group are not addressed attentively.

The digitalization of public services facilitating daily life, such as shopping, and banking, enables people with disabilities to carry out some activities in a way that is almost the same as 
those without disabilities [3]. People with disabilities are required to be able to adapt to the applicable concept of digitizing public services. There is a high demand for the disabled to adapt to technology quickly as it is expected would make it easier to receive public services, but it has not received the counterbalance of service providers' awareness to provide accessible information for this group. In this case, the disability groups remain as marginalized groups.

The issue of not fulfilling the right to the disabled who has an equal position with a nondisabled in the community is a hot topic to discuss. The issue does not only apply in developing countries but also occurred in developed countries. The Source of the problem is that people with disabilities are considered to be in the minority groups whose fulfillment of the rights of the State is often not a priority [4]. The interests of the majority often defeat the interests of minority groups, mostly due to efficiency considerations. There are many considerations by decision-makers in prioritizing the interests of serving community groups with a more significant number than prioritizing public services for fewer community groups. However, this cannot be allowed to persist, giving rise to a culture of disregarding the rights of a particular group of people, resulting in discriminatory treatment, which includes the service of financial institutions for disabled customers.

There is an incident in a bank that discrimination experienced by a person with a hearing disability. As he was called many times by voice, and he is unable to respond as there was no running text facility. After some time, he asked the staff as he did not realize that he was being called. When it was his turn, he did not receive a satisfactory service but instead was advised to open his savings in another bank. In the end, he decided not to have a transaction and stopped being a customer at the bank [5]. In banking services, its policies can result in discriminatory attitudes towards persons with disabilities when opening accounts independently. One of them requires an external agent for interpreting communication or for guardianship [6].

On top of the lack of staff understanding and application of service procedures, there is also related discrimination on the use of communication technology in banking services for persons with disabilities. It can be illustrated directly from the inaccessibility of several login pages on several bank sites, which are accompanied by 'graphic captcha' without audio messages [6]. This set up of financial product services has been considered as neglecting the condition of persons with visual impairment who have difficulties in accessing and filling visual information. Visual barriers experienced by visually impaired people have not been taken into consideration by the financial institution; as an example, ATM touch screen models have not been equipped with audio assistance.

People with visual impairment have the same rights to open a savings account personally under their name. Independent rights in these financial matters are guaranteed under Law No. 8 of 2016 on Disability and OJK Regulation No: 1 / POJK.07 / 2013 on Consumer Protection in the Financial Services Sector [7]. Therefore, there should be no discriminatory services to prospective customers with disabilities, including visually impaired customers, because each bank is obliged to serve the application for opening an account, even with special provisions [7].

Contradictively, in reality, discrimination still occurs. Therefore, this study aims to assess social conditions regarding this matter and also the person with visually impaired expectations of ATM services in order to establish the reality of the bank institution's service for the disabled, especially visually impaired people. 


\section{Methods}

This study uses quantitative descriptive methods with data collection techniques through questionnaires. Several questions elaborated from the available concept were asked to selected respondents and then calculated using the frequency distribution. The data is then analyzed and interpreted to be used as a material in concluding the research. The respondents who filled out the questionnaire were selected purposively with the criteria as follows: visually impaired, had a bank account, and had done transactions through an ATM. Forty-five respondents filled out the questionnaire through assistance. Assistance is carried out by enumerators in charge of reading questions and recording respondents' answers.

\section{Results/Preliminary Result}

In principle, persons with disabilities, including visually impaired people, have their assessment of social conditions relating to the fulfillment of their public service rights. The assessment is established out of the personal experience, as well as experiences gained from the environment. Based on the results of data collection and answers given by respondents, the assessment of social conditions has been constructed. The distribution of respondents' answers can be seen in Figure 1.

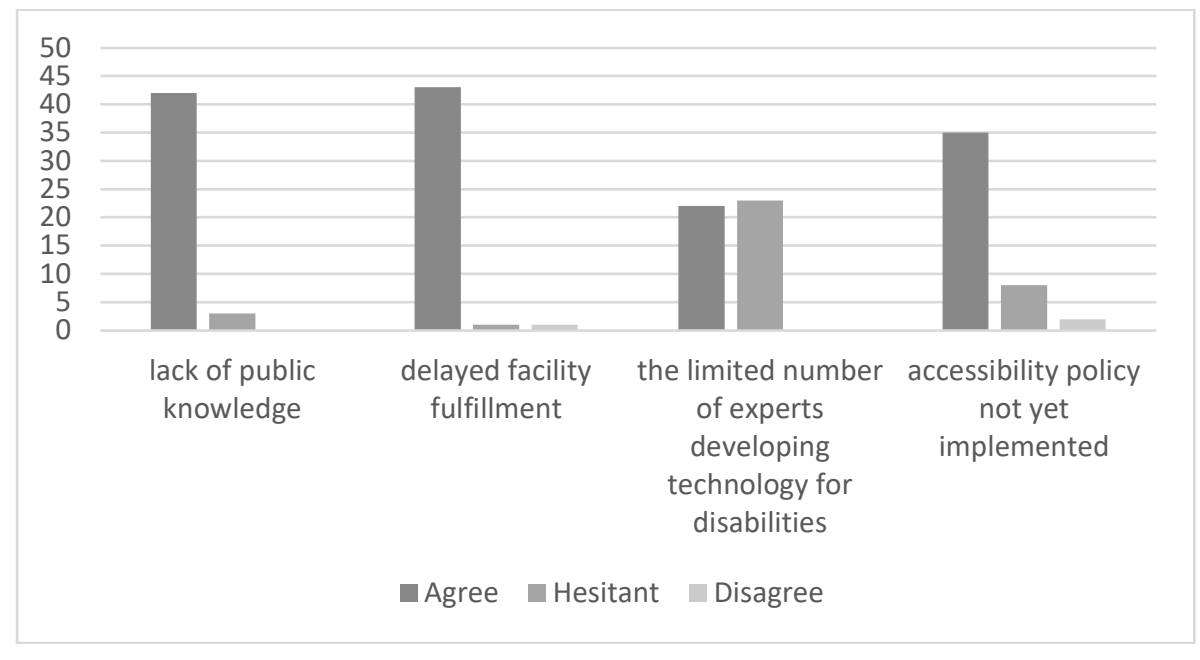

Fig.1. Assesment of Social Condition

Based on the data in Figure. 1, it is known that respondents have an understanding and assessment that their public service rights have not been fulfilled as members of the community due to lack of public knowledge, delayed facility fulfillment, and accessibility policy not yet implemented. This data shows that the majority of respondents are aware that it is a necessary effort to increase public awareness about the needs of disability in public services, the fast response of relevant parties to meet and provide public service facilities 
needed by disabled, and supervision to public service providers to implement accessibility policies for people with disabilities.

One of the supporting arguments in concordant with the results of this study shows the actual phenomenon of insufficient public knowledge about the needs of disability in public services. One of them is service from financial institutions, as it refers to the statement, which states that there are a majority of supporters of equal rights who seek to obtain microcredit for persons with disabilities, which in this case are not well informed of the applicable "rules of the game." At the same time, the microfinance community also lacks detailed information about disability issues [8]. Whereas for the fulfillment of facilities needed by the disabled in obtaining public services, there are still many obstacles, particularly in accessing content, experienced by people with visual impairments, even when assisted by a screen reader enable to convert visuals into an audio format [9], including when accessing information and banking service facilities.

There is also a problem of accessibility policy for persons with disabilities, in some lowincome countries, people with disabilities are not allowed to independently open and operate bank accounts or use banking facilities and services due to obstacles in the policy aspects. Such policy constraints are mostly based on the assumption of the capacity of persons with disabilities [10]. It can only mean that policy issues, not only experiencing obstacles at the implementation stage but also at the policy formulation stage itself, sometimes not in favor of people with interests on disability.

As for aspects of technology development to accommodate the needs of disability, it is stated that the use of technology in financial services through traditional banking and alternative services such as microfinance is being promoted and is attracting interest. This interest is due to its potential to reach many marginalized groups, who do not have bank accounts or even those who are not included in the consumer finance market [11]. However, other statements are stating that people with learning disabilities have difficulty accessing banking services, even though some service providers have tried to overcome these problems [12].

Therefore, it takes a more laborious effort from the technology developer to be willing to develop communication technology products that provide equal opportunities to the people with visually impaired in using the information technology [9]. Some examples, by creating standard documents for soft files that are disability-friendly. The term disability-friendly standardize soft file documents includes some of the following: (1) arranged in a logical reading and structure; (2) complete with pictures and descriptions; (3) alternative text descriptions for image fields, forms and links are available; (4) characters such as question marks, commas, and the like must be able to be converted into text so that consumers / prospective blind consumers can read them [13].

However, there are exciting findings on facilities and accessibility for persons with disabilities. Some disabled customers realize that as more technological facilities are provided by public service providers to accommodate the needs of persons with disabilities, the effectiveness would depend on the awareness of persons with disabilities to increase their ability to adapt to more advanced technological facilities. Therefore, enhancing the digital capabilities of the disabled should be increased gradually, by following technological developments gradually, in order to maximize the function of facilities that can be expensive.

The main priority on facilities for the disabled, which is considered the most important, is transportation, which is $36 \%$ - then followed by educational facilities $34 \%$, sidewalk facilities $16 \%$. Market facilities occupy the rest by $9 \%$, bank facilities by $3 \%$, and places of worship with a percentage of $2 \%$ [14]. Nevertheless, public services in terms of the availability of 
disabled-friendly public facilities such as schools, hospitals, offices, recreation areas, hotels, post offices, terminals, public telephones, banks, and other places have not yet provided the necessary accessibility for people with disabilities [15]. Therefore, there is a need to have strict rules or regulations for the protection of the rights of people with disabilities, especially for banking services [16]. However, strict regulation alone is not enough if it is not accompanied by initiatives to create public service formats from financial institutions that are appropriate to disability needs. One form of financial institution service that is down to earth and following the needs of disability and also the social and cultural conditions of Indonesian people is a microfinance institution in the form of cooperatives (or Koperasi). Microfinance institutions in the form of Koperasi tend to be chosen by the disabled because they have some advantages over the bank. The administrative procedures are considered more comfortable and uncomplicated, easy to access finances, administrators who are closer, and understand members' conditions [17].

In fact, for every visually impaired individual, there is a form of joint account that benefits prospective disabled customers, namely joint accounts, which guarantee the security of deposits for disabled customers [7]. Through this type of account, customers with a disability may have accounts with additional facilities, such as ATM cards. However, after having an account and an ATM card, it turns out that visually impaired customers tend to face other problems surrounding the use of ATM cards at ATM outlets. These problems generate expectations about things that needed to be improved for the accessibility of banking transactions through ATMs, which Figure 2. tries to illustrate.

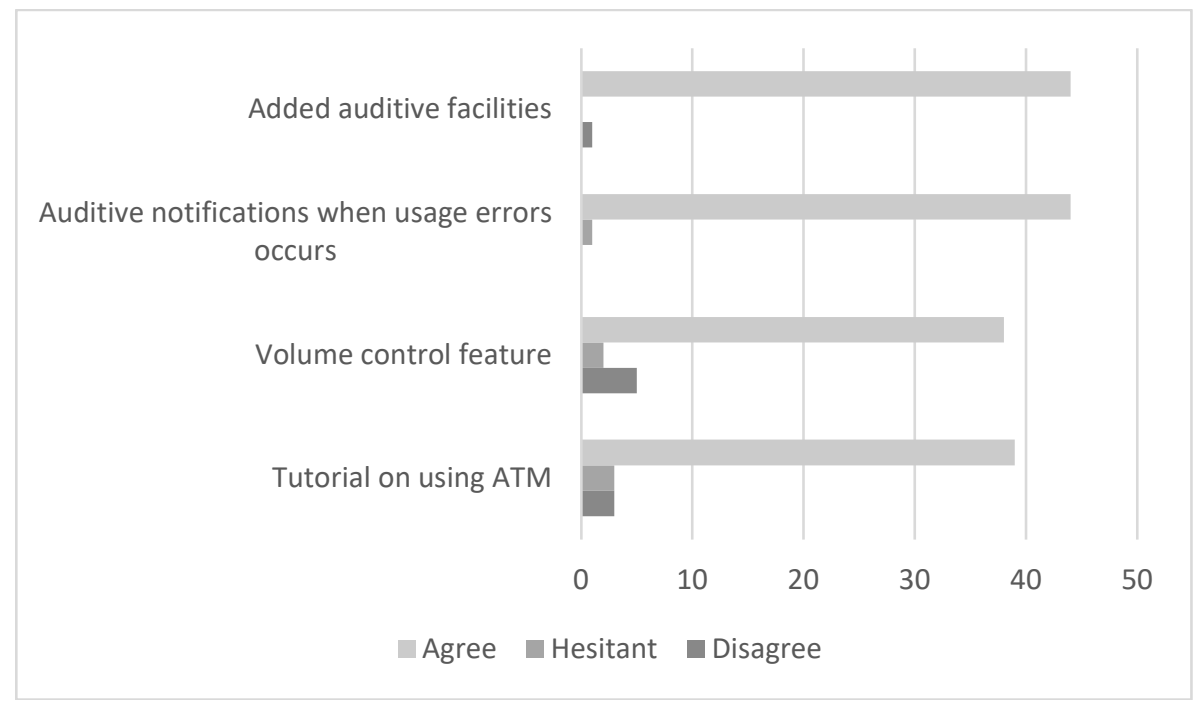

Fig.2. Person with Visually Impaired Expectations of ATM Services

The development of Banking and Financial Institutions can show the growth of a country's development. Digital literacy on Banking and Financial Institutions and their development in a country, depending on its use by citizens of a country[18]. Therefore, the respondent stated the need for a Tutorial on using ATM, volume control feature, auditive notifications when usage errors occur, and Added auditive facilities. 
A previous study shows that there are personal disabilities that blind customers have when dealing with ATMs. The personal constraints mentioned are limited knowledge of ATM locations, features listed on ATMs, not familiar with touch screens, inability to operate ATMs, English features, lack of understanding of instructions given by ATMs, concerns about incorrectly entering cards or PINs, cards swallowed by ATMs, and discrepancies in the amount of money that comes out [19].

On the one hand, it is natural that a blind person with disabilities wants a feature of added auditive facilities on an ATM. On the other hand, much technology also relies on auditory cues and signals. However, audio cues without any alternative text might not be picked up by customers who are using multimedia-based banking services or ATMs [20]. Therefore, although the will to equip facilities by adding voice recognition devices is quite common among consumers, the actual ability of speaker-independent systems in a crowded / noisy public environment does not seem to be significant and accurate enough [21].

Herein lies the urgency of providing appropriate technology for customers with disabilities. It takes hard work from technology developers to be able to produce findings and create tools to facilitate blind disabilities in accessing banking services [9]. The findings of the product are expected to have been carried out comprehensively in order to be a solution that does not leave new problems, which were only recently known.

For example, ATMs should be equipped with voice guidance features that can be accessed through the use of standardized audio jacks or telephone handsets. Also, the method to start using the voice assistance feature must be easy to find. For example, audio jacks at most ATMs with a sound/voice assistant are placed in prominent positions or stand out from the surface of the machine [22]. That is, if the additional equipment has been provided by the service provider, but has not been strategically placed in a position that is easily identified and understood by service users, then it is likely that those tools would be a waste of large-cost equipment.

\section{Conclusion}

Disability clients' assessments of social conditions are formed from the results of personal experience, as well as experience gained from the environment. Visually impaired customers have an understanding and assessment that their public service rights as members of the community have not been fulfilled due to the lack of public knowledge, delayed facility fulfillment, and accessibility policy not yet implemented. Those problems have implicated the importance of efforts to increase public awareness about the needs of people with disabilities for public services, the responsiveness of the parties concerned in contributing and provide the facilities needed by disabilities to obtain public services, and supervision of public service providers to implement accessibility policies for persons with disabilities, including the use of ATMs as a banking facility.

Therefore, visually impaired customers expect and hoping that, for ATM services, there is a need for tutorials on using ATM, volume control features auditive notifications when usage errors occur, and added auditive facilities. However, visually impaired customers noticed that the use of these facilities would not be useful if the lack of technology adaptation in the disabled group still occurs. 


\section{References}

[1] A. D. Johnsen, T.-M. Grønli, and B. Bygstad, "Making Touch-Based Mobile Phones Accessible for the Visually Impaired," Nor. Inform. Konf., pp. 177-188, 2012.

[2] P. Okonji, M. Lhussier, C. Bailey, and M. Cattan, "Internet use: Perceptions and experiences of visually impaired older adults," J. Soc. Incl., vol. 6, no. 1, pp. 120-145, 2015.

[3] B. A. Shawar, "Evaluating web accessibility of educational websites," Int. J. Emerg. Technol. Learn., vol. 10, no. 4, pp. 4-10, 2015.

[4] S. N. Syobah, "Pemberdayaan Penyandang Disabilitas Di Provinsi Kalimantan Timur," Nuansa, vol. 15, no. 2, pp. 251-272, 2018.

[5] M. Syafi, "Pemenuhan Aksesibilitas Bagi Penyandang Disabilitas," Inklusi, vol. I, no. 2, pp. 268-308, 2014.

[6] C. Singh, "Financial Inclusion of the Disabled," Indian Institute of Management Bangalore, 2017.

[7] I. P. Elkas and T. A. Ramli, "Hak Penyandang Tunanetra dalam Pembukaan Rekening Bank dihubungkan dengan Asas Non Diskriminasi menurut UU Nomor 8 Tahun 2016 tentang Penyandang Disabilitas Jo. Peraturan OJK Nomor: 1/POJK.07/2013 tentang Perlindungan Konsumen Sektor Jasa Keuangan," Pros. Ilmu Huk., vol. 1, pp. 158-163, 2016.

[8] R. Mersland, "Microcredit for self-employed disabled persons in developing countries," Atlas Alliance, Norway, 2005.

[9] H. Hafiar, P. Subekti, and A. R. Nugraha, "Internet Utilization by the Students with Visual Impairment Disabilities," Int. J. Emerg. Technol. Learn., vol. 14, no. 10, pp. 200-207, 2019.

[10] S. Thompson, "Mobile technology and inclusion of persons with disabilities," 2018.

[11] D. S. Raja, "Bridging the Disability Divide through Digital Technologies," World Bank Group, 2016.

[12] V. Williams, D. Abbott, J. Rodgers, L. Ward, and D. Watson, Money, Rights and Risks: A scoping review of financial issues for people with learning disabilities in the UK Val. Surrey: Friends Provident Foundation, 2007.

[13] Otoritas Jasa Keuangan, "Petunjuk Teknis Operasional (PTO) untuk Pelayanan Keuangan kepada Penyandang Disabilitas," 2018.

[14] S. Thohari, "Pandangan Disabilitas dan Aksesibilitas Fasilitas Publik bagi Penyandang Disabilitas di Kota Malang,” Indones. J. Disabil. Stud., vol. 1, no. 1, pp. 27-37, 2014.

[15] F. Priscyllia, "Kajian Hukum Terhadap Fasilitas Pelayanan Publik Bagi Penyandang Disabilitas," Lex Crim., vol. V, no. 3, pp. 105-112, 2016.

[16] S. V. Kasih, "Hambatan Bank Dalam Penyediaan Aksesibilitas Bagi Penyandang Disabilitas Sebagai Nasabah Tabungan Perbankan (Studi Di Bank BRI Dan Mandiri Kota Malang)," J. Huk., no. April, 2016.

[17] R. Nopiah and P. A. Islami, "Dampak Sosial-Ekonomi Koperasi Difabel Dan Perwujudan Microfinance Access.," Inklusi J. Disabil. Stud., vol. V, no. 2, pp. 217-238, 2018.

[18] P. J. M. Martin and M. Rabindranath, "Digital Inclusion for Access to Information: A Study on Banking and Financial Institutions in India," SAGE Open, no. July-September, pp. 1-8, 2017.

[19] H. Hafiar, P. Subekti, Y. Setianti, and K. Komariah, "The First Step Towards the Independence of the Visually Impaired in Entrepreneurship," Int. J. Entrep., vol. 23, no. Special Issue, pp. 1-7, 2019.

[20] D. S. Raja, N. Narasimhan, P. D’Intino, V. Maheshwari, and V. Montenegro, "Inclusive Financial Services, For Seniors and Persons with Disabilities: Global Trends in Accessibility Requirements," Global Initiative for Inclusive Information and Communication Technologies, 2015.

[21] G. I. Johnson and L. Coventry, “'You Talking to Me?' Exploring Voice in Self-Service User 'You Talking to Me?' Exploring Voice in Self-Service User Interfaces," Int. J. Hum. Comput. Interact., vol. 13, no. 2, pp. 161-186, 2001.

[22] J. C. Knisely and D. Morris, "Automated teller machine accessibility," Westlaw J. Bank Lender Liabil., vol. 18, no. 23, pp. 1-5, 2013. 
